\title{
Solar Energy Potential in Horn of Africa: A Comparative Study Using Matlab/Simulink
}

\author{
Erkan Dursun
}

\begin{abstract}
Geographically, the Horn of Africa is one of the regions that the Equator passes over, providing the opportunity for vigorous solar energy. However, despite the enormous solar energy resources, more than half of the region, 132 million populations have not yet access to electricity. This study presents an overview of the potential of solar energy in the region. Then review the current solar energy status and policies related to it. A Matlab/Simulink model is developed to show the comparative analyses of the solar radiation graphically on the photovoltaic modules and electricity outputs for the Horn of African countries' capitals. As a result of the simulation model, Ethiopia-Addis Ababa receives the highest annual solar radiation of 2915.03 $\mathbf{k W h} / \mathrm{m}^{2}$-year while Eritrea-Asmara with the lowest annual solar radiation of $2198.47 \mathrm{kWh} / \mathrm{m}^{2}$-year. The annual electrical output of the photovoltaic modules in Ethiopia-Addis Ababa is the highest with $286.685 \mathrm{kWh} /$ year and Eritrea-Asmara $216.214 \mathrm{kWh} / \mathrm{year}$ as the lowest in the region. The number of photovoltaic modules and the optimum tilt angles are calculated. For Ethiopia-Addis Ababa, the lowest photovoltaic module number is 10, and the optimum PV tilt angle is $11.163^{\circ}$. For Eritrea-Asmara, the highest photovoltaic module number is 14 , with a tilt angle of $15.397^{\circ}$.
\end{abstract}

Index Terms - The Horn of Africa, solar energy, Matlab

\section{INTRODUCTION}

$\mathrm{T}$ HE HORN of Africa refers to the eastern-most edge of Africa's mainland, which lies on the Indian Ocean to the east, Red sea to the northwest, and the Gulf of Aden to the north [1]. It is just a few hundreds of miles into the Arabian sea and has a link with Arabian Peninsula geographically and culturally. In terms of the geopolitical situation of the world, the region's location and its closeness connections to east and west of the world's maritime transport and energy supplies are a crucial factor of the region's importance with vast natural resources and minerals (Figure 1). Geographically, the region covers four states, which are Somalia, Ethiopia, Djibouti, and Eritrea, known as the horn of African countries [2-3].

Ethiopia has the highest population ratio, followed by Somalia, Eritrea, and Djibouti (Table 1), respectively.

ERKAN DURSUN is with Department of Electrical and Electronics Engineering, Marmara University, Istanbul, Turkey (e-mail: erkandursun@marmara.edu.tr).

(iD) https://orcid.org/ 0000-0002-7914-8379

Manuscript received May 12, 2021; accepted July 25, 2021. DOI: $\underline{10.17694 / \text { bajece. } 974404}$
According to Table 1, Eritrea has the highest annual population growth rate with $8.7 \%$, and Djibouti has the lowest with $1.5 \%$. Thus, a high-energy demand follows the high population growth rate.

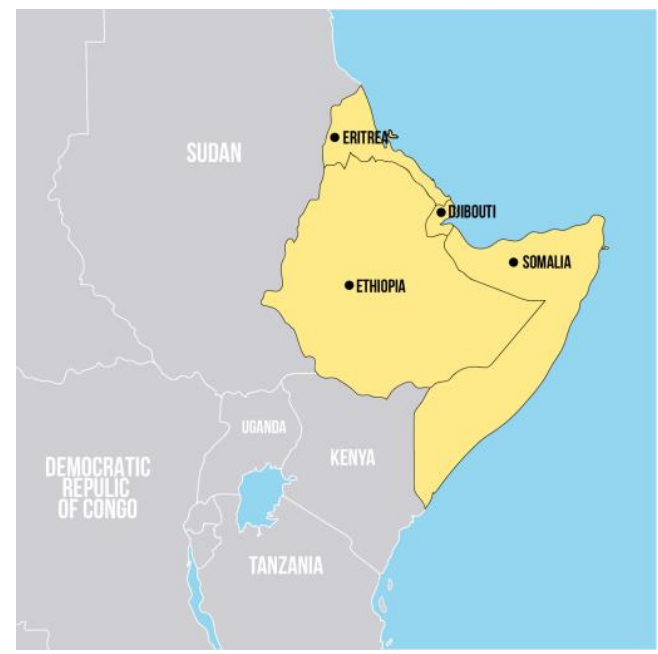

Fig. 1. The horn of Africa region map

TABLE I

HORN OF AFRICAN COUNTRIES PROFILE [4]

\begin{tabular}{|c|c|c|c|c|}
\hline Country & Area $\left[\mathrm{km}^{2}\right]$ & Population & $\begin{array}{c}\text { Population } \\
\text { growthrate } \\
{[\%]}\end{array}$ & $\begin{array}{c}\text { Urban } \\
\text { population }\end{array}$ \\
\hline Ethiopia & $1,000,000$ & $114,963,583$ & 2.57 & $21.695 \%$ \\
\hline Somalia & 637,657 & $15,893,219$ & 2.874 & $46.141 \%$ \\
\hline Eritrea & 101,000 & $3,608,143$ & 8.7 & $40.72 \%$ \\
\hline Djibouti & 23,200 & $1,005,379$ & 1.5 & $78.062 \%$ \\
\hline
\end{tabular}

The continuous rise in oil prices and environmental concerns of fossil fuels is pushing the horn of African countries to find alternative energy resources. Therefore, the solar energy potential of the Horn of Africa Countries has been analyzed in Section I. The calculated solar radiation values are evaluated in Section II. The regional problems and alternative solutions are reviewed in Section III.

\section{Solar EnERgy Potential of The Horn OF AFricA}

Most of the population of the horn of Africa live in rural and remote areas, as shown in Table 1. Due to lack of poor grid infrastructure, communities have no access to electricity. To 
overcome this issue, solar energy, with its vast availability throughout the year in the region, is the right option for off-grid applications. In the following section, the potential of solar energy for each country is reviewed separately.

\section{A. Somalia}

Somalia has a high potential for solar energy. Somalia annually receives an average of 2,900 to 3,100 hours of sunshine duration, which is ideal for solar energy utilization [5]. The country has one of the highest daily total solar radiation averages on the earth. Somalia's annual solar radiation estimation is over $2450 \mathrm{kWh} / \mathrm{m}^{2} / \mathrm{year}$, as shown in [Figure 2]. The daily average of solar radiation is $6.4 \mathrm{kWh} / \mathrm{m}^{2} /$ day. Furthermore, the country's average annual temperature is $27^{\circ} \mathrm{C}$, which is ideal for the operational life of Photovoltaic (PV) systems [6].

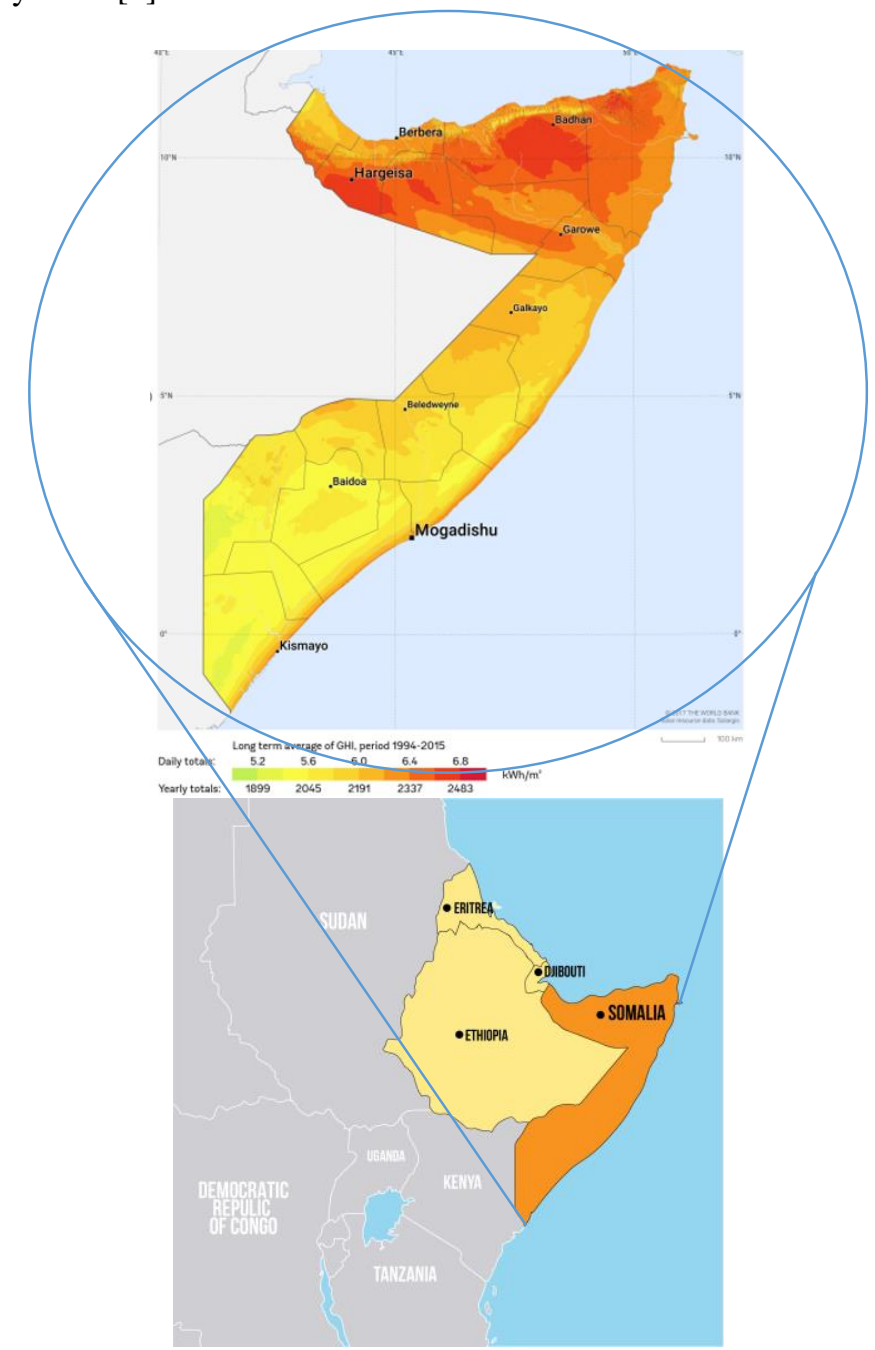

Fig. 2. Somalia solar energy potential map [7]

Over the past years, solar energy is progressively becoming a popular alternative among regional countries. However, the main barrier to develop this widely available energy resource is the traditional habits of the nations on using biomasses, charcoal, and firewood for energy consumption. Somalia dependents on foreign oil for practically $82 \%$ of its energy needs [8].

TABLE II
Monthly AVERage Solar Radiation in SOMALia [7]

\begin{tabular}{|l|c|c|}
\hline \multicolumn{1}{|c|}{ Months } & $\begin{array}{c}\text { Air temperature } \\
{\left[{ }^{\circ} \mathrm{C}\right]}\end{array}$ & $\begin{array}{c}\text { Daily solar } \\
\text { radiation } \\
{\left[\mathrm{kWh} / \mathrm{m}^{2} / \text { day }\right]}\end{array}$ \\
\hline January & 26.4 & 7.05 \\
\hline February & 26.7 & 7.15 \\
\hline March & 27.8 & 7.14 \\
\hline April & 28.9 & 6.76 \\
\hline May & 28.3 & 6.49 \\
\hline June & 26.4 & 5.72 \\
\hline July & 25.6 & 5.85 \\
\hline August & 25.6 & 6.59 \\
\hline September & 26.1 & 7.13 \\
\hline October & 27.2 & 7.15 \\
\hline November & 27.2 & 6.84 \\
\hline December & 27.0 & 6.63 \\
\hline
\end{tabular}

Most of the electricity consumption is supplied through diesel generators that are running on imported fuel. According to the African Development Bank study on Somalia, the country can potentially generate over $2,000 \mathrm{kWh} / \mathrm{m} 2$ of solar power. Due to higher tariffs of electricity compared to other countries such as Ethiopia and poor infrastructure, around 35\% of the country's population has access to electricity according to the United Nation's Somalia energy report.

The Banaadir Electric Company (BECO) is the largest energy provider in the country, operates in Mogadishu and its surroundings as well as some other cities like Kismayo, Afgoye, and supplies $50 \mathrm{MW}$ of electricity [9]. The company aims to increase its annual solar power generation capacity by $5.5 \mathrm{MW}$, gradually decreasing the share of power generation from fossil fuels, primarily diesel and coal to less than $40 \%$. PV panel installations do not only ensure the access of off-grid power to Somalia, but they also provide electricity to the communication infrastructure [10].

Apart from big cities in the country, there are no bank branches or electricity in the country, particularly in remote areas, which makes it difficult for the rural communities to charge their phones and banking activities. To overcome this, digital money transfers via mobile is in use in the country. As in Figure 3, the PV chargers are used for cell phones in remote areas.
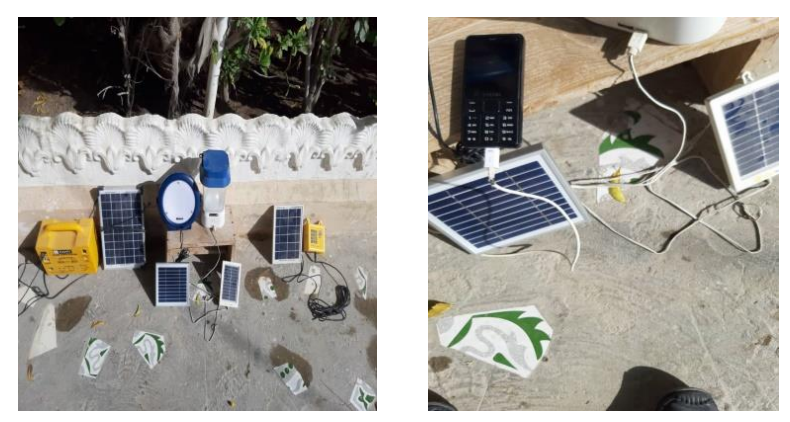

Fig. 3. Somalia's solar chargers for Mobiles and bills

Digital technologies are too expensive for the general public. Rural customers pay in small payments because they are not able to afford to pay the cost of PV panels. Occasionally, utilities have to take a combination of cash and swap with goats 
to make a deal. The natural abundance of the sun in Somalia makes it an attractive prospect for investment in renewable energy, particularly solar energy. However, the still-active conflicts in the country cause significant barriers to the investments in this tremendous and vast available solar source [11].

The challenges that influence the activities to exploit solar energy resources of the region. These challenges can be stated in two aspects such as PV installations capacity and finance. For Somalia's case, the main challenge to harness solar energy is public security and national energy regulation policy. With the overthrow of the central government of Somalia an internal conflict started. The national energy company went out of business and it is responsibilities for generation, transmission, and distribution vanished. Constituting new regulatory policies is a must for the development of the Somalia energy sector. Offgrid applications for mobile charging and lighting are on high demand, which is a huge opportunity for service providers. Diversification of solar technology systems such as lighting and mobile charging lanterns, water heaters, solar water pumps, and refrigerators is the untapped market, which is ready to invest by related companies. One of the alternative solutions to energy challenges in the horn of Africa is through education. Most of the population is not aware of the abundant solar resources in their region, thus educating the population could allow the rural community to adopt and harvest solar energy with the support of governments. Enforcement and development of energy regulations are also much needed to tackle the lack of electricity. Lowering solar product costs by evaluating the margins, such as entering product duty-free and freight charges. Introducing a different financial mechanism for solar energy consumers is an important aspect to get out of the lack of electricity in the horn of Africa [12-14].

\section{B. Djibouti}

PV systems are gaining significant interest in recent years in both on-grid and off-grid applications, especially refrigeration, lighting, communications, water pumping in Djibouti [15]. Due to the lack of proper infrastructures in rural areas, access to electricity is limited. Electricity generation is expensive. Also, grid infrastructure is lacking investment and maintenance. However, Djibouti has two maximum solar radiation periods between March-April and September-October [16-17]. The solar radiation changes are very slim among the highest and lowest values. It experiences the least amount of solar radiation in June, July, and August, but even in the following months, the country gets enough solar radiation around $5-6 \mathrm{kWh} / \mathrm{m}^{2} /$ day.

Djibouti has over 3000 hours/year of sunshine duration and solar radiation of $2300 \mathrm{kWh} / \mathrm{m}^{2} /$ year [Figure 4]. In line with the government's objective to increase the rural area electrification between 2010 and 2025 from $1 \%$ to $100 \%$, respectively [18].

Currently, the country imports $70 \%$ of its electricity from neighboring Ethiopian. Through the interconnected grid, and the remaining $30 \%$ comes from locally running diesel generation units [19]. Regarding the increasing population in the main cities, such as the capital Djibouti, the electricity demand is getting high and higher. The government improves energy regulations and creates financial support to the energy sector [20].

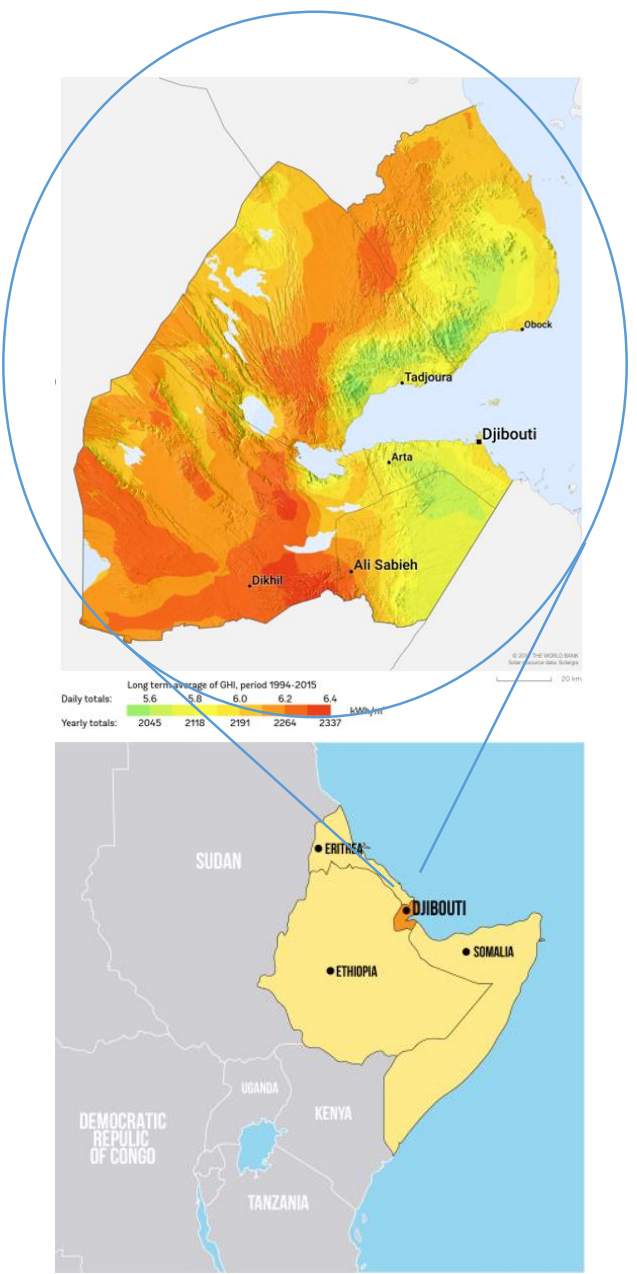

Fig. 4. Djibouti solar energy potential map [7]

TABLE III

MONTHLy AVERAge SOLAR RADiATION IN DJibOUTi [7]

\begin{tabular}{|l|c|c|}
\hline \multicolumn{1}{|c|}{ Months } & Air temperature $\left[{ }^{\circ} \mathrm{C}\right]$ & $\begin{array}{c}\text { Daily solar radiation } \\
{\left[\mathrm{kWh} / \mathrm{m}^{2} / \text { day }\right]}\end{array}$ \\
\hline January & 25.1 & 4.76 \\
\hline February & 25.7 & 5.60 \\
\hline March & 27.0 & 6.24 \\
\hline April & 28.7 & 6.57 \\
\hline May & 31.0 & 6.44 \\
\hline June & 34.2 & 5.79 \\
\hline July & 36.0 & 5.88 \\
\hline August & 33.1 & 5.96 \\
\hline September & 29.3 & 6.21 \\
\hline October & 26.9 & 6.10 \\
\hline November & 25.4 & 5.71 \\
\hline December & 36.0 & 5.08 \\
\hline
\end{tabular}

The rural population's access to electricity increased from $1 \%$ in 2010 to $30 \%$ in 2017 . The first solar power plant of $62 \mathrm{~kW}$ in Ali-Addeh, provides electricity to 203 households through the mini-grid system. The second one, $100 \mathrm{~kW}$ capacity power plant financed by Korean owned KC Cottrell with a cost of $\$ 2.5 \mathrm{M}$. The third one power plant is in the Dikhil district. The 
government of Djibouti is studying the energy needs of four main villages in the country. The Djiboutian Agency for Social Development (ADDS) will provide finance for the villages' energy projects. The ministry of energy is estimating the solar energy potential is as $70 \mathrm{MWh} /$ year. To diversify the power generating sources for the whole country through on-gird and off-grid solar energy solutions. Also, international investors have noticed this untapped solar potential in the country. The energy ministry announced several solar energy projects financed by foreign investors. A $300 \mathrm{MW}$ solar power plant with a cost of $€ 360 \mathrm{M}$ at the Grand Bara site and other smaller solar projects are notable projects which international investors will finance [21].

\section{Eritrea}

Most of the Eritrean highland regions receive around 2200 $\mathrm{kWh} / \mathrm{m} 2 /$ of solar radiation each year. This situation shows that solar energy is the right option to meet the population's energy needs in both central cities and rural areas (Figure 5).

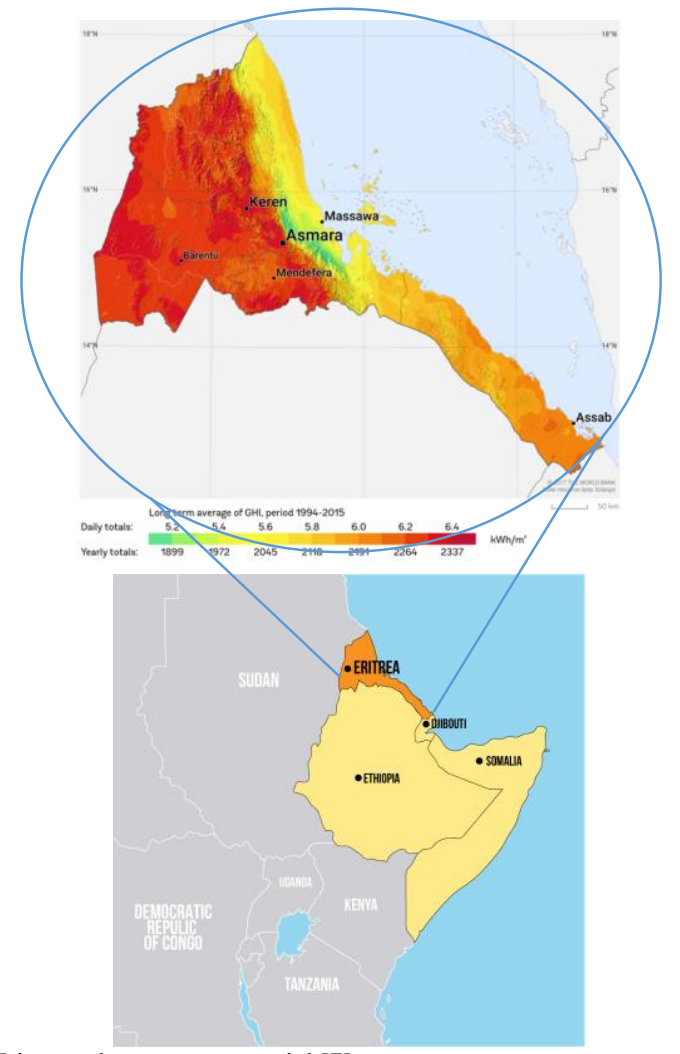

Fig. 5. Eritrea solar energy potential [7]

Till now, the installed solar energy systems in the country are generally for welfare purposes such as powering educational facilities, health stations, communications, village water pumping, and electricity generation. With more regulations and finance, it is possible to feed the main grid with PV systems as well as households in rural areas with solar energy. Average global solar radiation in Eritrea is varying between 5 to 6.55 $\mathrm{kWh} / \mathrm{m}^{2} /$ daily. Currently, traditional biomass is the leading alternative energy in Eritrea. The utilization of firewood and biomass makes up about $\% 78.25$ of the total energy output. PV panels are primarily used for electricity production in public buildings like health stations and educational centers [22]. Biomass-based energy was about $94.5 \%$ in the household sector, suggesting only a $5.4 \%$ contribution is from electricity, which shows poor access to the country's population to modern energy solutions. In 2009, the PV panel's electricity production accounted for only $0.04 \%$, which shows the low-level solar energy installation in the country [23]. $98 \%$ of the generated electricity in the country is from imported fossil fuels. These put a heavy financial weight on the government budget as it subsidizes this electricity. Moreover, due to outdated infrastructure in transmission lines and municipal grids, losses are rising to $23 \%$. The solar photovoltaic systems, solar water heaters, solar desalination plants, tobacco curing, solar crop dryers, solar cooling are among the possible investment opportunities of solar energy in Eritrea. Finally, the generation of electricity from biomass and imported fossil fuels leads to the pollution that contributes to climate change [24].

TABLE IV

MONTHLy AVERAge SOLAR RADIATION IN ERITREA [7]

\begin{tabular}{|l|c|c|}
\hline \multicolumn{1}{|c|}{ Months } & Air temperature $\left[{ }^{\circ} \mathrm{C}\right]$ & $\begin{array}{c}\text { Daily solar radiation } \\
{[\mathrm{kWh} / \mathrm{m} 2 / \text { day }]}\end{array}$ \\
\hline January & 18.9 & 5.18 \\
\hline February & 20.2 & 5.72 \\
\hline March & 22.1 & 6.23 \\
\hline April & 23.9 & 6.74 \\
\hline May & 25.0 & 6.68 \\
\hline June & 24.7 & 6.62 \\
\hline July & 21.7 & 6.05 \\
\hline August & 21.2 & 5.77 \\
\hline September & 22.1 & 6.19 \\
\hline October & 20.9 & 5.87 \\
\hline November & 19.8 & 5.27 \\
\hline December & 18.9 & 4.90 \\
\hline
\end{tabular}

Areza and Maidma towns of Eritrea had micro-grids installed this year, bringing clean power to 40,000 people funded by the government. It's a hybrid system that uses PV panels, batteries, and diesel generators for back-up. The project aims to serve more than 40,000 residents: 40 different neighborhoods, more than 513 small businesses, 17 education centers, 7 hospitals, as well as and 80 organizations. This $€ 11.7$ million project offers a replication model in other areas of Eritrea. The two plants have a generating capacity of $1.5 \mathrm{MW}$ of PV, $600 \mathrm{~kW}$ of a generator, $1 \mathrm{MW} \mathrm{PV}$, and $400 \mathrm{~kW}$ generators. These sites have been selected for being off-grid and densely populated areas [25].

Apart from Ethiopia, some of the ongoing solar energy projects in other countries in the region are summarized below.

TABLE V

Somalia, Dibouti, AND ERITREa Solar Projects [26]

\begin{tabular}{|c|l|l|l|l|l|}
\hline & $\begin{array}{l}\text { Project } \\
\text { Name }\end{array}$ & $\begin{array}{l}\text { Size } \\
{[\mathrm{MW}]}\end{array}$ & Country & Developer & Operator \\
\hline 1 & Grand Bara & 300 & Djibouti & Green, Enerys & EED \\
\hline 2 & $\begin{array}{l}\text { Jabad gelle } \\
\text { hybrid }\end{array}$ & 25 & Somalia & BECO & BECO \\
\hline 3 & Growe solar & 5.9 & Somalia & EPS & NECSOM \\
\hline 4 & $\begin{array}{l}\text { Areza, } \\
\text { Maidma }\end{array}$ & 2.25 & Eritrea & EEC & EEC \\
\hline 5 & Darusalam & 2.5 & Somalia & BECO & BECO \\
\hline
\end{tabular}




\section{Ethiopia}

The average annual solar radiation in the country is more or less uniform, and it's estimated around $5.2 \mathrm{kWh} / \mathrm{m}^{2} /$ day with seasonal variations [27].

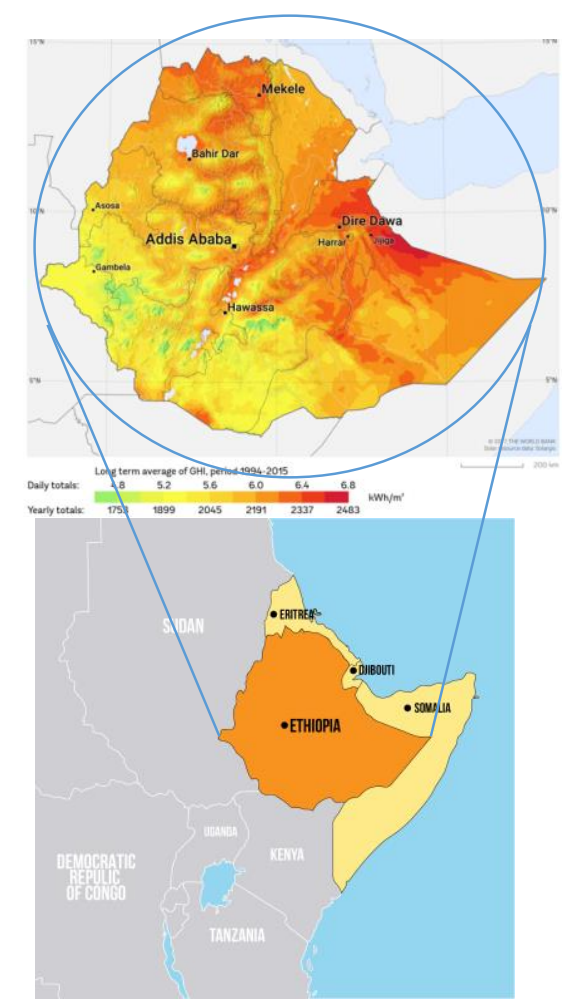

Fig. 6. Global horizontal irradiation map of Ethiopia [7]

Economically, Ethiopia is one of the world's fastest-growing nations, bringing an enormous increase in energy demand. Thus, it is expected the energy demand to growth $10-14 \%$ annually until 2037. Today just $27 \%$ of the citizens have electricity access [28]. To expand the $27 \%$ and connect more community to modern energy, the government is extending the main grid and increase the number of off-grid and mini-grid systems in the country. The majority of current PV electricity production is consumed in telecommunications. Also, other usages of existing solar power are health care centers, educational facility lighting, and village well pumps. The government is planning to connect over 150,000 households to electricity through PV systems. The first large PV plant installed in Ethiopia was a $10.5 \mathrm{~kW}$ village grid in 1985, and after four years in 1989, the PV plant is extended to $30 \mathrm{~kW}$ [29]. The Ethiopian government is planning to have over $500 \mathrm{MW}$ of installed solar capacity by 2020 [30].

Solar PV capacity in Ethiopia has almost tripled in the past five years. However, $14 \mathrm{MW}$ of solar PV systems has been installed up to now, counting for $0.3 \%$ of the Nation's total energy capacity. Ethiopia's solar capacity is expected to increase in the coming years with the number of ongoing solar PV projects [31]. Most of this installed $14 \mathrm{MW}$ solar PV capacity is used for telecom systems, both mobile and landline network stations. In May 2016, the state-owned power company Ethiopian Electric Power (EEP) initiated the Metahara project, which was Ethiopia's first solar plant tender for $100 \mathrm{MW}$.

TABLE VI

MONTH AVERAGE SOLAR RADIATION IN ETHIOPIA [7]

\begin{tabular}{|l|c|c|}
\hline \multicolumn{1}{|c|}{ Months } & Air temperature $\left[{ }^{\circ} \mathrm{C}\right]$ & $\begin{array}{c}\text { Daily solar } \\
\text { radiation } \\
{\left[\mathrm{kWh} / \mathrm{m}^{2} / \mathrm{day}\right]}\end{array}$ \\
\hline January & 15.9 & 5.48 \\
\hline Febuary & 16.4 & 5.47 \\
\hline March & 17.9 & 5.64 \\
\hline April & 17.6 & 5.27 \\
\hline May & 17.8 & 5.17 \\
\hline June & 17.0 & 4.47 \\
\hline July & 16.6 & 3.77 \\
\hline August & 15.0 & 3.73 \\
\hline September & 15.6 & 4.50 \\
\hline October & 15.8 & 5.47 \\
\hline Novermber & 15.2 & 5.65 \\
\hline December & 15.6 & 5.27 \\
\hline
\end{tabular}

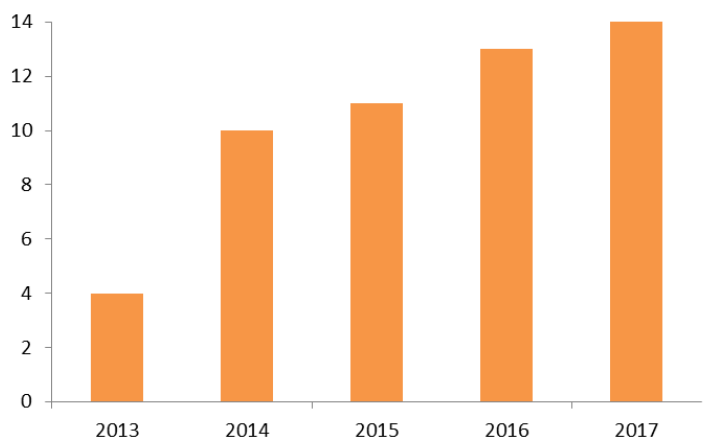

Fig. 7. PV size in Ethiopia (2013-2017)
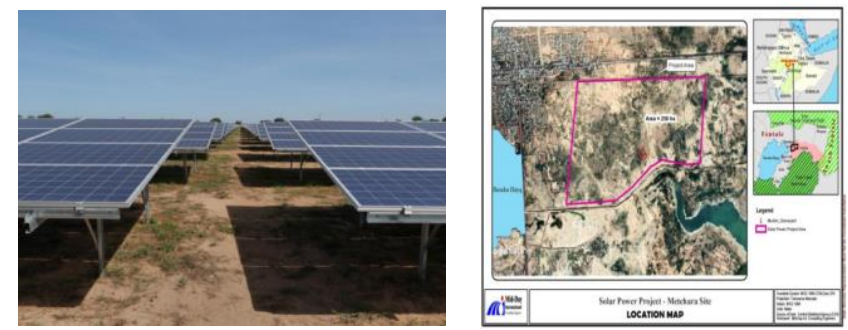

Fig. 8. Location of Metehara Solar PV Project [32]

In October 2017, the construction of two $125 \mathrm{MW}$ solar PV was launched in two regions Amhara and Dire Dawa of Ethiopia. The latest solar tender, which is $750 \mathrm{MW}$ of solar capacity, is initiated in this year of 2019 [33]. The Ethiopian finance ministry's Public-Private Partnership (PPP) Directorate General on 3 April 2019 launched a request for proposals for two 125MW PV projects being developed through the World Bank Group's Scaling Solar programme [34]. Following the successful issuance of the RFP for Ethiopia Round 1, PPP-DG (Public-Private Partnerships Directorate General) and EEP announced that it would be procuring up to an additional $750 \mathrm{MW}$ under the Scaling Solar initiative and formally requested IFC support to implement Ethiopia Scaling Solar Round 2. The RFQ process is ongoing [35-36] The Ethiopian government expects to make sure more than 7 million rural 
households to access electricity with stand-alone systems, by 2025 [37-38]. To prevent sub-standard or poor quality products from being flooded. The government approved regulations last year in December that enabled Ethiopian Energy Agency to specify minimum and maximum energy efficiency performance standards for appliances and equipment and provide efficiency certificates to wholesalers or retailers. The new regulation also gives priority to off-grid companies, which generate and supply power to off-grid areas. Some of the ongoing or announced solar projects are summarized below.

TABLE VII

ETHIOPIA's SOLAR PV PROJECTS [31]

\begin{tabular}{|c|l|c|c|l|l|}
\hline & $\begin{array}{c}\text { Project } \\
\text { Name }\end{array}$ & $\begin{array}{c}\text { Cost } \\
{[\$ \text { million] }}\end{array}$ & $\begin{array}{c}\text { Capacity } \\
{[\mathbf{M W}]}\end{array}$ & \multicolumn{1}{|c|}{ State } & Status \\
\hline 1 & Metehara & 120 & 100 & Oromia & Scaling Solar \\
\hline 2 & Humera & 120 & 100 & Tigray & Pending RFP \\
\hline 3 & Mekele & 120 & 100 & Tigray & Pending RFP \\
\hline 4 & Hurso & 150 & 125 & $\begin{array}{l}\text { Dire } \\
\text { Dawa }\end{array}$ & $\begin{array}{l}\text { Awaiting } \\
\text { approval }\end{array}$ \\
\hline 5 & Gad & 150 & 125 & Somali & Scaling solar \\
\hline 6 & Metema & 150 & 125 & Amhara & To approve \\
\hline 7 & Dicheto & 150 & 125 & Afar & Scaling solar \\
\hline 8 & Weranso & 165 & 150 & Afar & Pending RFP \\
\hline 9 & Welenchiti & 150 & 150 & Oromia & Pending RFP \\
\hline
\end{tabular}

\section{A COMPARATIVE CALCUlation MODEL FOR SOLAR POTENTIALS}

The solar radiation values that fall on the PV module are calculated for each day by taking the latitude, the longitude, and day numbers of the Horn of Africa countries. The calculated annual solar radiation values are shown graphically in Figure 11. The solar radiation falling on the PV module consists of three parts (Figure 9), such as diffuse radiation, beam radiation, and reflected radiation [39]. Calculations were made by modeling in Matlab Simulink environment (Figure 10).

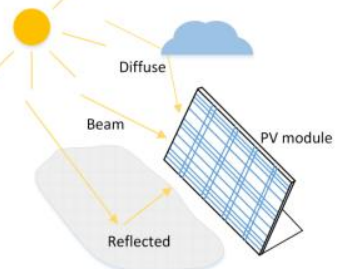

Fig. 9. Solar radiation types striking on the module [40]

$\delta=23.45 \sin \left[\frac{360}{365}(n-81)\right]$

$\beta_{A}=90-L+\delta$

$P V_{\text {tilt }}=90-\beta_{A}$

$\delta=$ Solar declination angle

$\beta_{A}=$ Altitude angle, The altitude angle is the angle between the sun and the local horizon directly

beneath the sun.
$P V_{\text {tilt }}=$ Optimum $\mathrm{PV}$ panel tilt angle

$L=$ the latitude of the site.

$n=$ day number

$I_{\text {total }}=I_{\text {beam }}+I_{\text {diffuse }}+I_{\text {reflected }}$

$I_{\text {beam }}=I_{B H} R_{B}$

$I_{B H}=I_{H}-I_{D H}$

$R_{B}=\frac{\cos \left(L-P V_{t i l t}\right) \cos \delta \sin H_{S R C}+H_{S R C} \sin \left(L-P V_{t i l t}\right) \sin \delta}{\cos L \cos \delta \sin H_{S R}+H_{S R} \sin L \sin \delta}$

$H_{S R}=\cos ^{-1}(-\tan L \tan \delta)$

$H_{S R C}=\min \left\{\cos ^{-1}(-\tan L \tan \delta), \cos ^{-1}\left[-\tan \left(L-P V_{t i l t}\right) \tan \delta\right]\right\}$

$C=\frac{I_{H}}{I_{O}}$

$\frac{I_{D H}}{I_{H}}=1.390-4.207 C+5.531 C^{2}-3.108 C^{3}$

$I_{\text {diffuse }}=I_{D H}\left(\frac{1+\cos \left(P V_{t i l t}\right)}{2}\right)$

$I_{O}=\left(\frac{24}{\pi}\right) S C\left[1+0.034 \cos \left(\frac{360 n}{365}\right)\right]\left(\cos L \cos \delta \sin H_{S R}+H_{S R} \sin L \sin \delta\right)$

(13)

$I_{\text {reflected }}=\rho I_{H}\left(\frac{1-\cos \left(P V_{\text {tilt }}\right)}{2}\right)$

$I_{\text {total }}=$ Total daily solar radiation on the PV module

$I_{\text {beam }}=$ Beam solar radiation on the PV module

$I_{\text {diffuse }}=$ Diffuse solar radiation on the PV module

$I_{\text {reflected }}=$ Reflected solar radiation on the PV module

$I_{H}=$ Total average daily horizontal solar radiation

$I_{B H}=$ Beam radiation on the horizontal surface

$R_{B}=$ Beam tilt factor

$H_{S R C}=$ The sunrise hour angle for the collector (when the sun first strikes the

collector face, $\theta=90^{\circ}$ )

$H_{S R}=$ The sunrise hour angle (in radians)

$C=$ Clearness index

$I_{O}=$ Extraterrestrial insolation on a horizontal surface the site

$I_{H}=$ Insolation on a horizontal surface

$\rho=$ Ground reflectivity

As in Figure 11 depicts, Ethiopia has the highest solar radiation, while Eritrea has the lowest solar radiation. In these calculations, the annual solar radiation values of each city are obtained with the proposed MATLAB model.

Mogadishu, Addis Ababa, Asmara, and Djibouti's annual solar radiation are used to calculate the number of PV modules and the optimum tilt angles concerning the typical load profile. The annual average electrical energy of the load group created for this study is 2,759.4 $\mathrm{kWh}$ (Table 8).

TABLE VIII

TYPICAL DAILY LOAD PROFILE IN THE HORN OF AFRICA REGION

\begin{tabular}{|l|l|l|l|l|}
\hline Appliances & $\#$ & $\begin{array}{l}\text { Running } \\
\text { hours/day }\end{array}$ & $\begin{array}{l}\text { Power } \\
{[\mathrm{W}]}\end{array}$ & $\begin{array}{l}\text { Energy } \\
{[\mathrm{Wh}]}\end{array}$ \\
\hline Refrigerator & 1 & 6 & 200 & 1200 \\
\hline Air conditioner & 1 & 4 & 1500 & 6000 \\
\hline Lighting & 4 & 5 & 18 & 360 \\
\hline
\end{tabular}




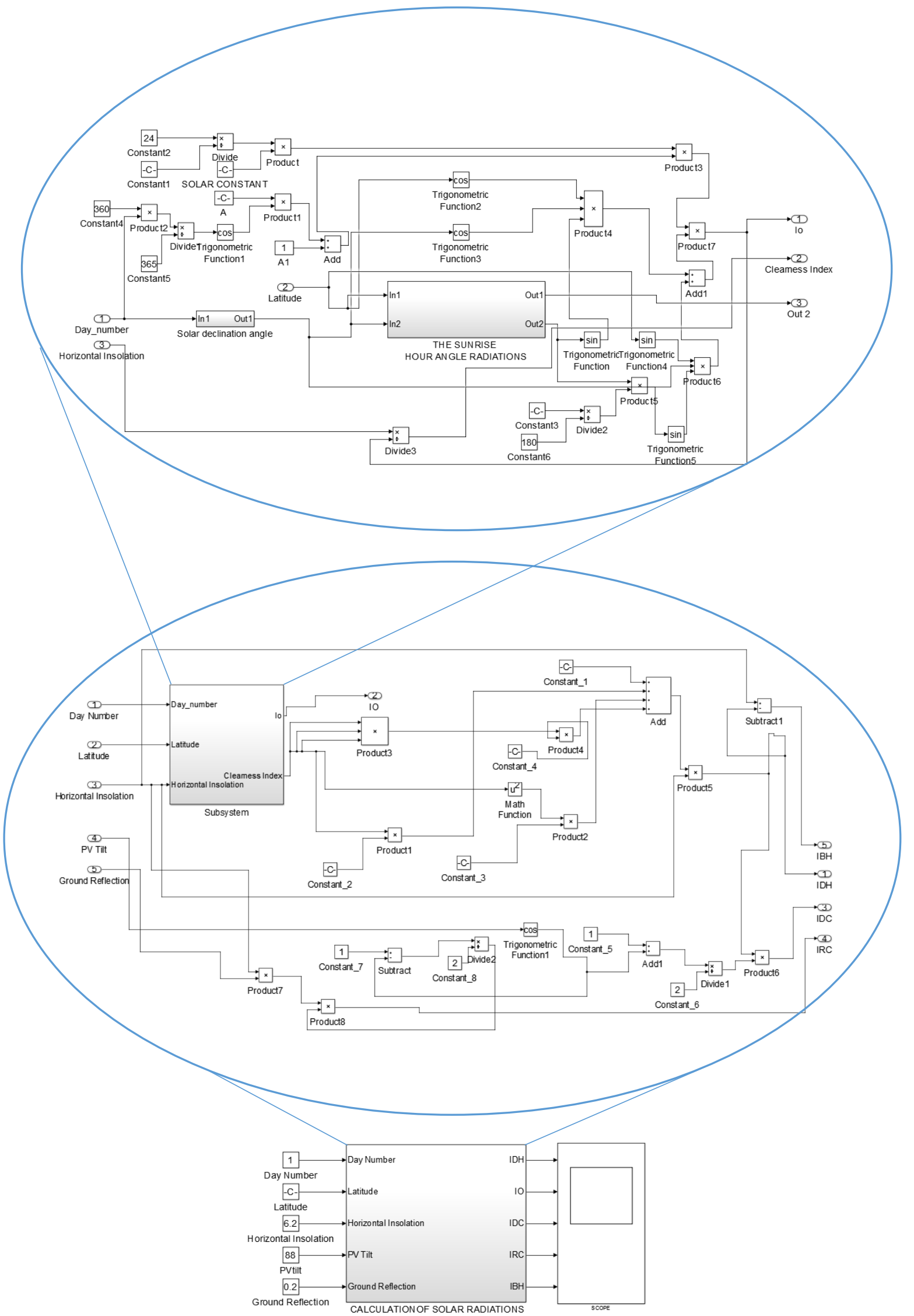

Fig.10. Created Matlab-Simulink model for solar calculations of The Horn of Africa 


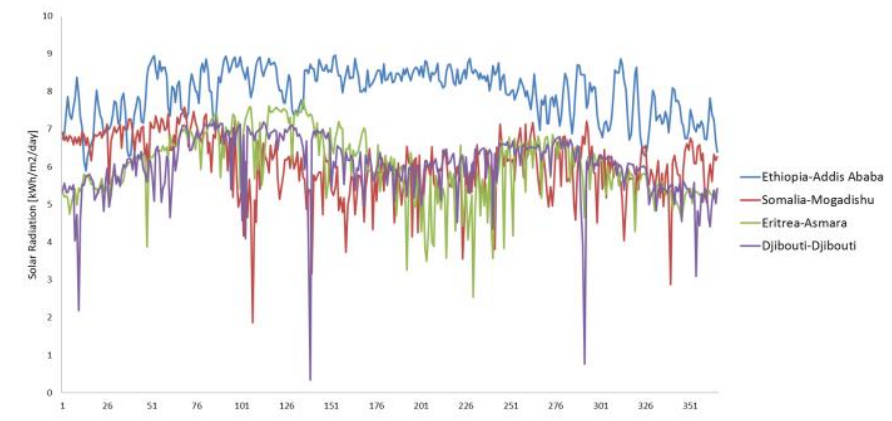

Fig.11. Annual solar radiation model outputs for the horn of African countries

When Table 9 is analyzed, it is seen that citizens of the Horn of Africa country have very low access to electricity. While forming the load group, the average energy consumption is taken into consideration rather than the electricity access rates. Although the average energy consumption per capita in the world is $2770 \mathrm{kWh}$ per year, this rate is around $570 \mathrm{kWh}$ per year in African countries [33].

TABLE IX

ELECTRICITY ACCESS RATES OF THE HORN OF AFRICA COUNTRIES [41]

\begin{tabular}{|l|c|}
\hline Country & $\begin{array}{r}\text { Percentage of Population with access to } \\
\text { electricity [\%] }\end{array}$ \\
\hline Ethiopia & 26.6 \\
\hline Somalia & 32.7 \\
\hline Eritrea & 36.1 \\
\hline Djibouti & 53.3 \\
\hline
\end{tabular}

Average daily energy consumption of a typical house based on a sample load model in the region is $11.490 \mathrm{kWh} /$ day, 344.7 $\mathrm{kWh} /$ month. The average house annual energy consumption in the horn of African countries is $4136.4 \mathrm{kWh}$. The technical details of the sample PV module are shown in Table 10.

TABLE X

JKM380M-72H SOLAR MODULE CHARACTERISTICS [42]

\begin{tabular}{|l|l|}
\hline Cell Type & Mono-crystalline \\
\hline No.of Half-cells & $144(12 \times 12)$ \\
\hline Dimensions & $1987 \times 992 \times 40 \mathrm{~mm}$ \\
\hline Weight & $22.5 \mathrm{~kg}$ \\
\hline Maximum Power (Pmax) & STC $(380 \mathrm{Wp})$ \\
\hline Maximum Power Voltage (Vmp) & $40.5 \mathrm{~V}$ \\
\hline Maximum Power Current (Imp) & $9.39 \mathrm{~A}$ \\
\hline Open-circuit Voltage (Voc) & $48.9 \mathrm{~V}$ \\
\hline Short-circuit Current(Isc) & $9.75 \mathrm{~A}$ \\
\hline Module Efficiency STC $(\%)$ & $19.28 \%$ \\
\hline Operating Temperature $\left({ }^{\circ} \mathrm{C}\right)$ & $-40{ }^{\circ} \mathrm{C}+85^{\circ} \mathrm{C}$ \\
\hline Maximum system voltage & $1000 \mathrm{~V} \mathrm{DC}($ IEC) \\
\hline Maximum series fuse rating & $20 \mathrm{~A}$ \\
\hline Temperature coefficients of Pmax & $-0.37 \% /{ }^{\circ} \mathrm{C}$ \\
\hline Temperature coefficients of Voc & $-0.29 \% /{ }^{\circ} \mathrm{C}$ \\
\hline Temperature coefficients of Isc & $0.048 \% /{ }^{\circ} \mathrm{C}$ \\
\hline Nominal operating cell temperature (NOCT) & $45 \pm 2{ }^{\circ} \mathrm{C}$ \\
\hline Power tolerance & $0 \sim+3 \%$ \\
\hline
\end{tabular}

$P F=0.86, A_{\text {cell }}=0.0225, A_{\text {module }}=0.93, \mathrm{n}=54$

$\eta_{\text {cell }}=\% 16.4$ $\eta_{\text {module }}=\eta_{\text {cell }} . \mathrm{PF} \gg \% 16.4 * 0.86=0.141$

$A_{\text {module }}$ is $0.93 \mathrm{~m}^{2}$ and $\eta_{\text {module }}$ is calculated as 0.141

$E_{\text {total }}=A \cdot \eta \cdot H \cdot P R$

Where,

$E_{\text {total }}=$ Total produced energy from the PV module $[\mathrm{kWh}]$

$A=$ Total solar panel area $[\mathrm{m} 2]$

$\eta=\mathrm{PV}$ module efficiency [\%]

$H=$ Annual average of solar radiation (shadings not included) on tilted PV modules.

$P R=$ Performance ratio, coefficient for losses (range 0.5 to 0.9 , default value $=0.75$ ).

$P R$ is a significant value for determining the quality of a photovoltaic installation [43]. It gives the installation performance regardless of inclination and the orientation of the module. It includes all losses. Ethiopia-Addis Ababa receives the highest annual solar radiation (2915.03 kWh/m2-year) followed by Somalia-Mogadishu (2215.47 kWh/m2-year) then Djibouti-Djibouti $\left(2212.73 \mathrm{kWh} / \mathrm{m}^{2}\right.$-year) of solar irradiation and Eritrea with the lowest annual solar irradiation 2198.47 $\mathrm{kWh} / \mathrm{m}^{2}$-year. Where $\mathrm{n}$ is the season's number of days and $P V_{\text {tilt }}$ is optimum $\mathrm{PV}$ module tilted angle.

TABLE XI

THE CAPITALS ANNUAL SOLAR RADIATION, TOTAL ANNUAL OUTPUT ENERGY AND PV MODULE NUMBER

\begin{tabular}{|l|c|c|c|c|}
\hline Country/City & $\begin{array}{c}\text { Total } \\
\text { annual } \\
\text { solar } \\
\text { radiation } \\
{[\mathrm{kWh} / \mathrm{m}} \\
2-\mathrm{year}]\end{array}$ & $\begin{array}{c}\text { Total } \\
\text { output } \\
\text { energy of } \\
\text { the system } \\
{[\mathrm{kWh} / \mathrm{k} \text { /yr] }}\end{array}$ & $\begin{array}{c}\text { Optimum } \\
\text { PV } \\
\text { module } \\
\text { number }\end{array}$ & $\begin{array}{c}\text { Optimum } \\
\text { PV tilt } \\
\text { angle }\end{array}$ \\
\hline Ethiopia-Addis Ababa & 2915.03 & 286.685 & 10 & $11.163^{\circ}$ \\
\hline Somalia-Mogadishu & 2215.47 & 217.885 & 13 & $2.118^{\circ}$ \\
\hline Eritrea-Asmara & 2198.47 & 204.017 & 14 & $15.397^{\circ}$ \\
\hline Djibouti-Djibouti & 2212.73 & 217.616 & 13 & $11.900^{\circ}$ \\
\hline
\end{tabular}

Ethiopia-Addis Ababa has the highest total annual solar radiation, which is $2915.03 \mathrm{kWh} / \mathrm{m}^{2}$-year, and Eritrea has the lowest $2198.47 \mathrm{kWh} / \mathrm{m}^{2}$-year. In terms of the total annual output energy of the PV system, Ethiopia has the lowest PV module number of 10 and an optimum PV tilt angle (fixed system) of $11.163^{\circ}$. In contrast, Eritrea-Asmara have the highest with 14 of PV module numbers with $15.397^{\circ}$ of optimum PV tilt angle respectively.

\section{CONCLUSIONS}

More than half of the population of the region lives in rural and remote areas. Due to lack or weak grid infrastructure, most of these areas, communities have not accessed to electricity, which makes it isolated. To overcome this issue, solar energy with its vast availability throughout the year in the region, is the right option through off-grid solutions.

In this study, annual average solar radiation values that will fall to the off-grid PV system to be established for a typical 
house in Horn of Africa countries are calculated on MatlabSimulink model. Calculations were made by taking into account the number of days, latitude-longitude angles of the region where the PV system will be installed and the PV inclination angles of the optimum. Comparative analyses of the capitals of the countries in the region were performed. As a result of the calculations, Ethiopia-Addis Ababa receives the highest annual solar radiation $\left(2915.03 \mathrm{kWh} / \mathrm{m}^{2}\right.$-year $)$ while Eritrea with the lowest annual solar irradiation of $\left(2198.47 \mathrm{kWh} / \mathrm{m}^{2}\right.$-year). The total annual energy output of the PV system is also calculated as Ethiopia has the highest with $286.685 \mathrm{kWh} /$ year and Eritrea $216.214 \mathrm{kWh} /$ year as the lowest in the region. Calculations of PV module number and optimum tilt angle are conducted with Ethiopia has the lowest PV module number (10) with the optimum PV tilt angle of $11.163^{\circ}$, Somalia (13) with $2.118^{\circ}$, Eritrea (14) with $15.397^{\circ}$ and Djibouti both (13) of PV modules with $11.9^{\circ}$.

\section{REFERENCES}

[1] AEEP (Africa EU Energy Partnership), "Country Power Market Brief: Djibouti,” Jan. 12, 2021. www.ruralelec.org/fileadmin/ DATA/Documents/06_Publications/Market_intelligence/AEEP_Djibo uti_Country_market_brief_EN.pdf.

[2] EIA (Energy Information Administration), Jan. 20, 2021. https://www.eia.gov/beta/international/regionstopics.php?RegionTopi $\mathrm{cID}=$ WOTC

[3] B. Pillot, M. Muselli, P. Poggi, P. Haurant, I. Hared, "The first disaggregated solar atlas of Djibouti: A decision-making tool for solar systems integration in the energy scheme," Renewable Energy, 2013, vol. 57, pp. 57-69.

[4] AfDB (African Development Bank). "The Horn of Africa Opportunity," Jan. 2021. https://www.afdb.org/fileadmin/uploads/afdb/Documents/GenericDocuments/Investing_in_Transition_States-

_The_Horn_of_Africa_Opportunity__A_briefing_note_for_South_Korean_investors.pdf

[5] J.M. Huacuz, L. Gunaratne, Photovoltaics and Development, in: Handbook of Photovoltaic Science and Engineering, Wiley, England, 2003, pp. 1043-1071.

[6] U. Deichmann, C. Meisner, S. Murray, D. Wheeler, "The economics of renewable energy expansion in rural Sub-Saharan Africa," Energy Policy, 2011, vol. 39, pp. 215-227.

[7] World Bank Group, Energy Sector Management Assistance Program, Solargis [Online] Available: https://globalsolaratlas.info/map

[8] State Minister for Environment, Office of the Prime Minister and Line Ministries and Ministry of Planning Federal Government of Somalia, "Somalia's intended nationally determined contributions," Jan. 12, 2021.https://www4.unfccc.int/sites/ndcstaging/PublishedDocuments/S omalia\%20First/Somalia\%27s\%20INDCs.pdf

[9] International Labor Organization (ILO), "Scoping study for a renewable energy skills development Public Private Development Partnership (PPDP) in Somalia" Apr. 2021. https://www.ilo.org/wcmsp5/groups/public/---africa/---ro-abidjan/--sro-addis_ababa/documents/publication/wcms_547596.pdf

[10] BECO (The Banaadir Electric Company). https://www.beco.so/

[11] P.A Trotter, R. Maconachie, M.C. McManus, "Solar energy's potential to mitigate political risks: The case of an optimised Africa-wide network," Energy Policy, 2018, vol. 117, pp. 108-126.

[12] N. Plain, B. Hingray, S. Mathy, "Accounting for low solar resource days to size $100 \%$ solar microgrids power systems in Africa," Renewable Energy, 2019, vol. 131, pp. 448-458.

[13] Federal Government of Somalia and African Development Bank, "Somalia: Energy Sector Need Assessment and Action/Investment Programme," Apr. 16, 2021

https://www.afdb.org/fileadmin/uploads/afdb/Documents/GenericDocuments/Final_Somalia_Energy_Sector_Needs_Assessment_FGS_ _AfDB_November_2015.pdf
[14] The United Nations Children's Fund (UNICEF), "Evaluation of the Performance of Solar Powered Water Systems in Somalia," Apr. 18, 2021. https://www.unicef.org/evaldatabase/index_95035.html

[15] B. Pillot, M. Muselli, P. Poggi, J.B. Dias, "Satellite-based assessment and in situ validation of solar irradiation maps in the Republic of Djibouti," Solar Energy, 2015, vol. 120, pp. 603-619.

[16] International Renewable Energy Agency (IRENA), "Renewable energy technologies cost analysis series-biomass," Apr. 22, 2021. https://www.irena.org/publications/2012/Jun/Renewable-Energy-CostAnalysis---Biomass-for-Power-Generation

[17] A.I. Omar, J. Virgone, E. Vergnault, D. David, A. I. Idriss, "Energy Saving Potential with a Double-Skin Roof Ventilated by Natural Convection in Djibouti," Energy Procedia, 2017, vol. 140, pp. 361-373.

[18] M. Mussard, M. Amara, "Performance of solar photovoltaic modules under arid climatic conditions: A review," Solar Energy, 2018, vol. 1741, pp. 409-421.

[19] S. Baurzhan, G.P. Jenkins, "Off-grid solar PV: Is it an affordable or appropriate solution for rural electrification in Sub-Saharan African countries?" Renewable and Sustainable Energy Reviews, 2016, vol. 60, pp. 1405-1418.

[20] International Renewable Energy Agency (IRENA), "Djibouti Renewables readiness assestment,” Apr. 23, 2021. https://www.irena.org/-

/media/Files/IRENA/Agency/Publication/2015/IRENA_RRA_Djibout 2015_EN.pdf

[21] Djibouti Social Development Agency. http://www.adds.dj/en/ruralelectrification-ali-addeh-adds-strengthens-the-capacity-of-the-central/

[22] IEA (International Energy Agency) https://www.iea.org/countries/Eritrea

[23] International Energy Agency (IAE) International Renewable Energy Agency (IRENA), United Nations Statistics Division, World Bank Group, "2019 The Energy Progress Report," Apr. 19, 2021. https://sustainabledevelopment.un.org/content/documents/2019_Track ing_SDG7_Report.pdf

[24] Climate Technology Centre \& Network and United Nations Industrial Development Organization (UNIDO), Apr. 25, 2021. https://www.ctcn.org/content/eritrea-2012

[25] S. Cox, P. Gagnon, S. Stout, O. Zinaman, A. Watson, E. Hotchkiss, "Distributed generation to support development-focused climate action," United States Agency for International Development (USAID) and National Renewable Energy Laboratory (NREL), Apr. 25, 2021. https://www.nrel.gov/docs/fy16osti/66597.pdf

[26] The main issues and opportunities were identified in the "EU TAF for the SE4All initiative - Eastern and Southern Africa, Mission to Eritrea in the energy sector" report, October 2014.

[27] United States Agency for International Development (USAID), "OffGrid Solar Market Assessment," Apr. 25, 2021. https://www.usaid.gov/sites/default/files/documents/1860/PAOPEthiopia-MarketAssessment-Final_508.pdf

[28] Solar Energy Development Association Ethiopia, Ethio Resource Group (ERG), "Solar energy vision for Ethiopia Opportunities for creating a photovoltaic industry in Ethiopia," Apr. 28, 2021. https://www.sun-connect-news.org/fileadmin/DATEIEN/PV-IndustryET-04-09-12_final.pdf

[29] G. A. Tiruye et al, "Opportunities and Challenges of Renewable Energy Production in Ethiopia," Sustainability, 2021, vol. 13, 10381.

[30] World Bank, "Project Appraisal Document on a Proposed Credit in the Amount of SDR 86.0 Million (US\$ 130 million Equivalent) to the Federal Democratic Republic of Ethiopia for a Second Electricity Access Rural Expansion Project," Apr. 30, 2021. https://documents1.worldbank.org/curated/en/154751468038131697/p df/38158.pdf

[31] Ministry or Finance and Economic Development, "Federal Democratic Republic of Ethiopia (2015) The Second Growth and Transformation Plan,"Apr.30, 2021. http://extwprlegs1.fao.org/docs/pdf/eth144893.pdf

[32] Solar Energy Development Association Ethiopia, Ethio Resource Group (ERG), "Off-grid solar development in Ethiopia: Market intelligence study report'. Addis Ababa: Ethiopia Resource Group. Study commissioned by the Climate and Development Knowledge Network (CDKN)," May, 12, 2021. https://cdkn.org/wpcontent/uploads/2018/09/Ethiopia-Solar-Power-PB_for-web.pdf

[33] E. Baker, M. Fowlie, D. Lemoine, S.S. Reynolds, "The Economics of Solar Electricity," Annual Review of Resource Economics, 2013 vol. 5: Submitted. Doi: 10.1146/ annurevresource-091912-151843 
[34] International Renewable Energy Agency (IRENA), 2012a. Renewable energy technologies: Cost analysis series; Volume 1: Power Sector Issue 2/6, Concentrating Solar Power.

[35] Cross-border Information (CbI), https://www.africa-energy.com/livedata/article/ethiopia-scaling-solar-rfp-launched

[36] Cross-border Information https://www.ifc.org/wps/wcm/connect/f4df6171-1018-4003-ad9d938ce4866c15/scaling-infra-solar08.pdf?MOD=AJPERES\&CVID=Msczfcy

[37] World Bank Group, Apr. 10, 2021. https://www.scalingsolar.org/active-engagements/ethiopia/

[38] World Bank, Apr. 12, 2021. http://documents.worldbank.org/curated/en/724741556102180951/pdf /Environmental-and-Social-Impact-Assessment-for-Metehara-SolarPower-PV-Plant.pdf

[39] R. Celikel, A. Gundogdu, "Comparison of PO and INC MPPT methods using FPGA in-the-loop under different radiation conditions", Balkan Journal of Electrical\&Computer Engineering, vol.9, 2, pp. 114-122.

[40] Gilbert M. Masters, Renewable and Efficient, Electric Power Systems, John Wiley \& Sons, Inc., Hoboken, New Jersey

[41] United Nations Environment Programme (UNEP), Apr. 11, 2021. https://wedocs.unep.org/

[42] Jinko Solar, JKM380M-72H solar module. Apr. 13, 2021. https://jinkosolar.eu/files/jinko/module/datasheets\%2007.2019/SWAN \%20DG\%20JKM380-400M-72H-BDVP-F40-A2-EN.pdf

[43] O. Cicek, M.A.M. Millad, F. Erken, "Energy prediction based on modelling and simulation analysis of an actual grid-connected photovoltaic power plant in Turkey", European Journal of Technique (EJT), vol. 9, 2, pp. 2019.

\section{BIOGRAPHIES}

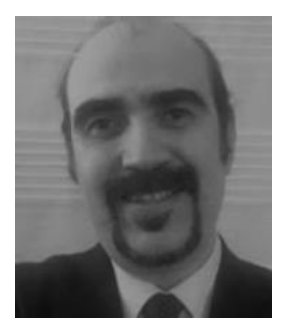

Erkan Dursun (Member, IEEE) received the B.Sc., M.Sc., and Ph.D. degrees in Electric Education from the Faculty of Technical Education, Marmara University, Istanbul, Turkey, in 2001, 2006, and 2013, respectively. From 2010 to 2012, he was a Visiting Fellow with the United Nations Industrial Development Organization-International Centre for Hydrogen Energy Technologies (UNIDO-ICHET). From 2012 to 2013, he was a Researcher with the Joint Research Center, European Commission, Italy. His research interests include distributed generation, hybrid power systems, and smart grid. His papers have received more than 600 citations in SCI database of Thomson Reuters 